\title{
Tropical turmoil: a biodiversity tragedy in progress
}

\author{
Corey JA Bradshaw ${ }^{1,2,3^{*}}$, Navjot S Sodhi ${ }^{4}$, and Barry W Brook ${ }^{1}$
}

All is not well for biodiversity in the tropics. Despite recent debate over the extent of future tropical extinctions and the effectiveness of reserve systems, the continued disappearance of habitat, soaring human population, and loss of vital ecosystem services demand immediate action. This crisis is worrying, given that tropical regions support over two-thirds of all known species and are populated by some of the world's poorest people, who have little recourse to lower environmental-impact lifestyles. Recent evidence has shown that - in addition to unabated rates of forest loss - coastal development, overexploitation of wildlife, catchment modification, and habitat conversion are threatening human well-being. We argue that the recent technical debate about likely extinctions masks the real issue - that, to prevent further loss of irreplaceable tropical biodiversity, we must err on the side of caution. We need to avoid inadvertently supporting political agendas that assume low future extinction rates, because this will result in further destruction of tropical biodiversity.

Front Ecol Environ 2009; 7(2): 79-87, doi:10.1890/070193 (published online 24 Jun 2008)

$\mathrm{D}$ espite some claims to the contrary, tropical biodiversity is in serious trouble. A recent flurry of scientific papers on the future of tropical biodiversity (reviewed in Laurance 2007) could give the impression that the state of tropical environments is not as dire as is widely believed. Tropical forests harbor more than $60 \%$ of all known species (Laurance 1999; Dirzo and Raven 2003), yet they represent only $7 \%$ of the Earth's land surface. Documenting the state of this key biome is therefore an endeavor of paramount importance. As much as we would like to be bearers of good

\section{In a nutshell:}

- The majority of the world's most threatened biodiversity hotspots are found in the tropics

- Habitat loss is continuing at unprecedented rates, with rainforests, savannas, mangroves, and coral reefs in particular peril in Southeast Asia

- Extinction rates from habitat loss and overexploitation are acute in the tropics, given the high species richness of these habitats

- The loss and degradation of essential ecosystem functions (eg pollination, carbon sequestration, water cycling) and services (eg flood mitigation, topsoil retention, non-timber forest products) are threatening billions of people living in tropical countries

- Poor governance and corruption are some of the principal socioeconomic threats to tropical biodiversity conservation

${ }^{1}$ Research Institute for Climate Change and Sustainability, School of Earth and Environmental Sciences, University of Adelaide, Adelaide, South Australia, Australia *(corey.bradshaw@adelaide.edu.au); ${ }^{2}$ South Australian Research and Development Institute, Henley Beach, South Australia, Australia; ${ }^{3}$ School for Environmental Research, Charles Darwin University, Darwin, Northern Territory, Australia; ${ }^{4}$ Department of Biological Sciences, National University of Singapore, Singapore, Republic of Singapore

Beyond the Frontier: Listen to Corey Bradshaw discussing this research on Frontiers' monthly podcast, at www.frontiersinecology.org. news, the sad reality is that tropical biodiversity has never been in worse shape.

The debate mentioned above began with an analysis by Wright and Muller-Landau (2006) of current trends in tropical deforestation and human demographic projections. They predicted that a tropical extinction crisis would be largely averted, because the rate of secondary regrowth would outstrip that of deforestation as rural human populations shifted into urban domains. Subsequent critiques of those predictions (reviewed in Laurance 2007) challenged assumptions regarding (1) the inverse relationship between urban and rural human population trends, (2) the notion of decreasing demand for forest resources as urban populations expand, (3) human poverty projections (MA 2005), (4) the relatively lower biodiversity harbored by secondary forests compared to primary forests (eg Barlow et al. 2007; Laurance 2007; references therein), (5) the extinction debt in already depleted populations, and (6) the drivers of continued deforestation.

Laurance (2007) concluded that the tropical extinction crisis was unlikely to be averted by human migration to urban areas. Yet, the debate highlights an important question: is there evidence that tropical ecosystems are sufficiently intact to safeguard existing biodiversity into the immediate future? We address this question by outlining the current state of knowledge of tropical biodiversity and evaluating whether there is sufficient cause for concern. Our conclusion is that we are already squarely in the midst of a tropical biodiversity tragedy and on a trajectory toward disaster.

\section{Habitat loss - any improvement?}

It is predicted that habitat loss will affect terrestrial ecosystems more directly and profoundly than in even 
some of the worst-case scenarios for climate change, invasive species, and overexploitation (Sala et al. 2000). Table 1 summarizes the available measurements of habitat loss for tropical rainforests, savannas, and mangroves. An average of $1.2 \%$ of total rainforest area is lost each year, equivalent to $>15$ million hectares per year, or an area greater than that of Bangladesh (Laurance 1999). Rates of deforestation are proportionally highest in Asia (where more than $40 \%$ of rainforests have already been lost; Wright 2005), followed by Central and South America and Africa (Table 1). These figures have been disputed as conservative, because they do not include catastrophic events such as extreme forest fires, and they may erroneously include plantations as native forest cover (Matthews 2001; Grainger 2008). Although the Asian estimates were recently revised downward, to $0.52 \%$ per year (Table 1), they still demonstrate that Asia has the highest proportional rate of rainforest loss (Table 1).

Have deforestation rates declined in recent years? Data from the United Nations Food and Agriculture Organization (FAO 2007) suggest that they have, especially for Latin America. However, rates continue to increase in tropical Asia (Matthews 2001). Hansen and DeFries (2004) reported recently that deforestation rates, as measured using satellite imagery, have accelerated by as much as 30\% over the past decade. More recent work suggests that estimated rates of decline are suspect, due to differences in statistical design, questionable or varying data sources, and secondary growth (Grainger 2008). As mentioned previously, however, there is now evidence that secondary forests support less native biodiversity than do primary forests (Barlow et al. 2007). Regardless of the precision associated with particular estimates (Grainger 2008), the general consensus is that rates of tropical forest loss are higher now than ever before (Laurance 1999; Figure 1). Rainforests are not the only tropical habitats in peril; major losses of tropical savannas and mangroves have also been reported (Table 1).

\section{Prioritization of conservation areas in the tropics}

The finite economic and logistical resources available for conservation require optimizing the investment of funds to maximize biodiversity preservation. However, the method of allocation depends upon the priorities placed on different biodiversity values (Brooks et al. 2006). For instance, if the goal is to protect areas of high endemism that are under severe threat from habitat loss, concepts such as terrestrial biodiversity "hotspots" (Myers et al. 2000; BH in Figure 2) or BirdLife International's Endemic Bird Areas (Orme et al. 2005; EBA in Figure 2) are typically applied. Yet hotspots of species endemism, threat, and richness are not geographically congruent on a global scale (at least for some taxa; Orme et al. 2005), nor do they typically take latent risk into account (Cardillo et al. 2006), assess the implications of the loss of ecosystem services (Kareiva and Marvier 2007), or consider the optimal trade-off between dollars spent and number of endemic species conserved (Wilson et al. 2006). Conservation International's update of Myers' hotspots demonstrates the particular threat faced by tropical biodiversity, given that 20 of the 34 global hotpots are found in the tropics (www.biodiversityhotspots.org; $\mathrm{BH}$ in Figure 2). The lack of congruence among methods

Table 1. A summary of the rates of terrestrial habitat loss occurring in tropical regions

\begin{tabular}{llll}
\hline Region & $\begin{array}{l}\text { Rate of loss or } \\
\text { degradation } \\
\left.\text { (million ha } \mathrm{yr}^{-1}\left[\% \mathrm{yr}^{-1}\right]\right)\end{array}$ & Period & Source \\
\hline Rainforests & $15.4[1.2]$ & $1980-1990$ & Whitmore (1997); Laurance (1999) \\
All tropical forests & $10[0.75]$ & $1980-1990$ & Whitmore (1997); Laurance (1999) \\
South and Central America & $6[1.10]$ & $1980-1990$ & Whitmore (1997); Laurance (1999) \\
Asia & $5[0.70]$ & $1980-1990$ & Whitmore (1997); Laurance (1999) \\
Africa & $5.8[0.52]$ & $1990-1997$ & Achard et al. (2002) \\
All tropical forests & $2.5[0.38]$ & $1990-1997$ & Achard et al. (2002) \\
South and Central America & $2.5[0.91]$ & $1990-1997$ & Achard et al. (2002) \\
Southeast Asia & $0.85[0.43]$ & $1990-1997$ & Achard et al. (2002) \\
Africa & & & \\
Sumatra, Kalimantan, Sulawesi, & 1.5 & $1980-1999$ & DeFries et al. (2002) \\
$\quad$ West Papua (Indonesia) & 3.1 & $1990-1997$ & Achard et al. (2002) \\
Tropical forest converted to agriculture & {$[0.8]$} & $1990 \mathrm{~s}$ & Matthews (2001) \\
All native tropical forests & & & \\
Savannas & {$[5]$} & $1990 \mathrm{~s}$ & Sinclair and Arcese (1995); Sinclair et al. (2002) \\
Tanzania & {$[1.5]$} & $1970-2005$ & Klink and Machado (2005); \\
Brazilian cerrado & {$[0.2]$} & $1950-1990$ & MA (2005) \\
All savannas & & & \\
Mangroves & {$[2-8]$} & $1918-1993$ & Adeel and Pomeroy (2002) \\
All mangroves & & &
\end{tabular}


also suggests that particular tropical refugia of high species richness, such as tropical uplands (Orme et al. 2005), may be sacrificed if decision makers are relying solely on measures of endemism to allocate resources. Nonetheless, the majority of prioritization methods indicate that the tropical realm contains many areas deserving of conservation priority (Figure 2).

\section{Extinction and overexploitation}

Given such extensive tropical habitat destruction, which species are being lost? Global extinction rates have soared over the past century, due predominantly to habitat destruction and burgeoning human populations (MA 2005). Human action is implicated in a 100 - to 10000 -fold increase in the species extinction rate expected from gradual environmental change, newly established competitive interactions, and occasional chance catastrophes (Dirzo and Raven 2003; Brook et al. in press). Furthermore, extinctions of a large number of cryptic or poorly studied taxa (many tropical) may have gone unnoticed.

Pimm and Raven (2000) estimate that 10000 to 10 million species now become extinct each decade; they predict that future deforestation alone may lead to the disappearance of $40 \%$ of the species in Myers' 25 hotspots. BirdLife International (2000) predicts that at least $13 \%$ of bird species across the globe may be extinct or consigned to extinction within 100 years, $99 \%$ of them due to deforestation and hunting. This modern crisis may eventually rival the scope of the five largest prehistoric extinction events. At the estimated yearly loss of $0.8 \%$ of forests globally, log-linear species-area curves have been used to predict that between 0.1 and $0.3 \%$ of tropical forest species - that is, 14000 to 40000 species - may be disappearing annually (Hughes et al. 2007).

It should be noted that, because they ignore a number of real-world feedbacks, both positive and negative, species-area curves do not necessarily provide realistic predictions of extinction rates. The regeneration of secondary forests may be rapid enough to equalize or overcome the rate of clearance of pristine habitat (Wright and Muller-Landau 2006). The preponderance of biases in species-area projections are, however, negative, due to the additional impact of climate change, invasive competitors and predators, acceleration of forest clearance driven by growing economic demand for mature rainforest timber, and, perhaps most insidiously, by the synergistic interactions among these threats (Brook et al. in press).

For vertebrates, $31 \%, 12 \%$, and $20 \%$ of known amphibian, bird, and mammal species, respectively, are currently threatened (IUCN 2007). Amphibian populations have undergone catastrophic declines worldwide, with some species driven to extinction and others facing the same prospect. The highest percentage of rapidly declining amphibian species occurs in Central and South America (Stuart et al. 2004). Indonesia, India, Brazil, and China are among the countries with the most threatened bird and mammal species (IUCN 2007). Plant species are also rapidly declining in Central and South America, Central and West Africa, and Southeast Asia (IUCN 2007).

The associated "bushmeat" crisis (overhunting of wildlife by humans for consumption; Figure 3) is now one of the gravest threats to tropical animal biodiversity. This is because deforestation also inevitably causes habitat fragmentation, which reduces dispersal, while logging trails increase access to forest interiors, thereby facilitating hunter access (Brook et al. in press). Poor governance and civilian access to advanced weapons also contribute to increasing mortality for many tropical species (Smith et al. 


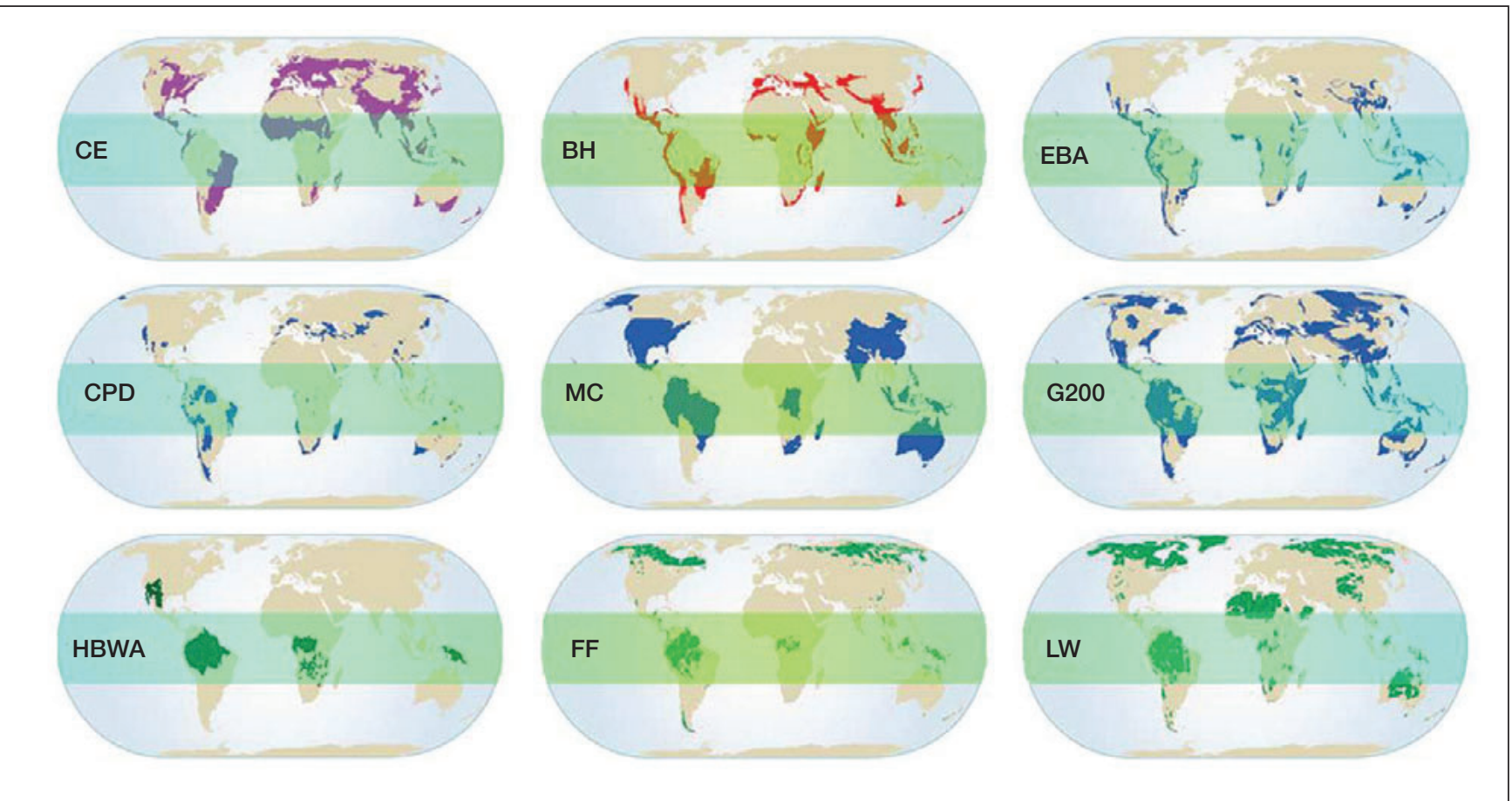

Figure 2. Global biodiversity conservation priority areas based on nine different methods of prioritization (see Brooks et al. [2006] for specific details): $\mathrm{CE}=$ crisis ecoregions; $\mathrm{BH}=$ biodiversity hotspots; $\mathrm{EBA}=$ endemic bird areas; $\mathrm{CPD}=$ centers of plant diversity; $\mathrm{MC}$ = megadiversity countries; $\mathrm{G} 200$ = global 200 ecoregions; HBWA = high-biodiversity wilderness areas; $\mathrm{FF}=$ frontier forests; $L \mathrm{~W}=$ last of the wild. The highlighted band represents the tropics between the tropics of Cancer and Capricorn $\left(23.5^{\circ}\right.$ north and south of the equator). Adapted from Brooks et al. (2006), with permission from AAAS.

2003). Wildlife is extracted from tropical forests at approximately six times the sustainable rate (Table 2), with the overall biomass of vertebrate communities declining with increasing hunting pressure (Peres 2000). As such, the quantity (and, probably, the diversity) of animals hunted by humans is diminishing. Within the past 40 years, up to 12 large vertebrate species have been extirpated from Vietnam alone, due primarily to excessive hunting (Milner-Gulland and Bennett 2003). Human population expansion in the tropics will almost certainly lead to more wildlife hunting,

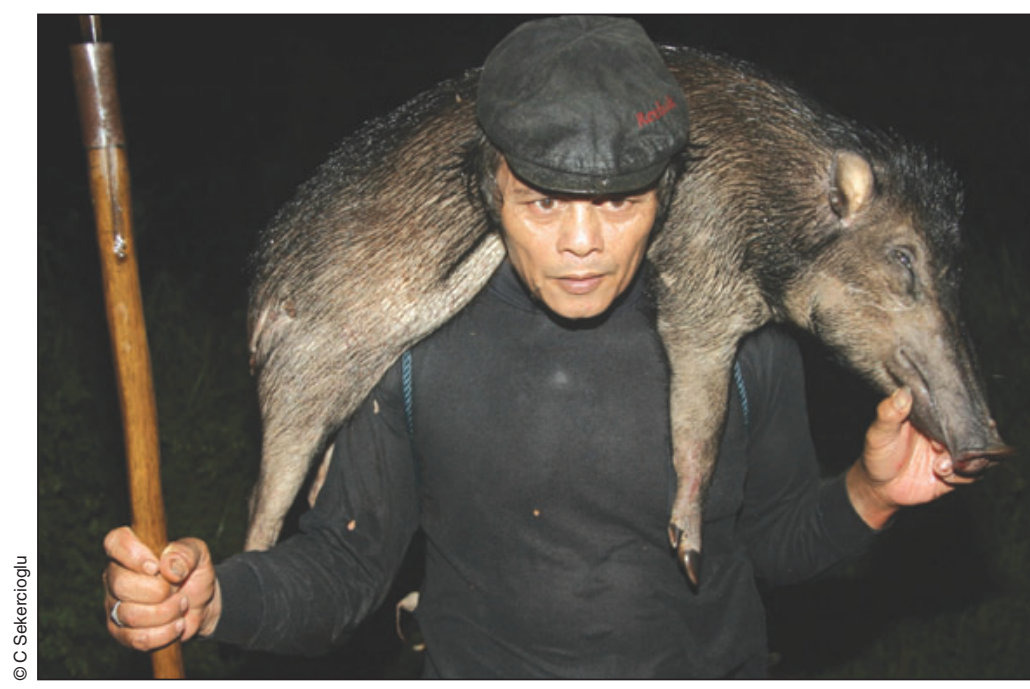

Figure 3. An endemic Sulawesi wild pig (Sus celebensis) killed for local consumption as bushmeat. given the positive correlation between human density and total wildlife harvest (Robinson and Bennett 2004).

\section{Invasive species}

It is intuitive that habitat loss and overexploitation of species lead to higher extinction rates, yet there are other, more subtle pressures also altering tropical communities. Invasive, non-indigenous species, spread mainly through human agency, may affect biodiversity just as severely as other high-profile threats, such as climate change (see Vitousek et al. [1996] and below). Invasive species can (1) cause extinctions of native biota, (2) alter abiotic environments, such as nutrient cycles and fire regimes, (3) become agricultural pests, and (4) harm humans or native species through the introduction or facilitation of virulent diseases. Of the 680 documented animal species extinctions, 20\% were probably caused by invasive species (Clavero and García-Berthou 2005).

Of the world's 100 worst invasive species, 56 are found in the tropics (ISSG 2007). For example, the introduction of brown tree snakes (Boiga irregularis) to Guam (Figure 4) caused the loss of 12 of 18 native bird species and the decline of other vertebrates (Fritts and Rodda 1998), while the introduction to Hawai' $i$ of the mosquito Culex quinquefasciatus, a vector of avian malaria 
Table 2. Estimates of hunting rates and available biomass in the tropics

\begin{tabular}{cccll}
\hline $\begin{array}{l}\text { Millions of animals } \\
\text { shot annually }\end{array}$ & $\begin{array}{l}\text { Equivalent weight of } \\
\text { meat consumed or } \\
\text { harvested (million } \mathrm{kg} \mathrm{yr}^{-1} \text { ) }\end{array}$ & $\begin{array}{c}\text { Estimated total } \\
\text { biomass (million kg) }\end{array}$ & Region & Source \\
\hline 2.6 & 24 & - & Sarawak & Bennett et al. (2000); Bennett (2002) \\
I.I & - & - & Sabah & Bennett et al. (2000); Bennett (2002) \\
- & 48.8 & 58.0 & Central African Republic & Fa et al. (2003) \\
- & 148 & 4160 & Amazon & Fa et al. (2002) \\
- & 12.9 & 18.9 & Equatorial Guinea & Fa et al. (2003) \\
- & 49.1 & 252.8 & Gabon & Fa et al. (2003) \\
- & 189.2 & 237.1 & Republic of Congo & Fa et al. (2003) \\
- & 0.02 & $0.02^{*}$ & Peru (3l4-km area) & Alvard et al. (1997) \\
23.5 & - & - & Brazilian Amazon & Peres (2000) \\
Notes: " = estimated maximum sustainable harvest & & &
\end{tabular}

(Plasmodium relictum; Figure 5d), has caused the decline and extinction of some 60 species of endemic forest bird (van Riper et al. 1986). Similarly, the introduction of the predatory Nile perch (Lates nilotica) caused one of the most devastating invasion-induced extinction events known: introduced into Lake Victoria in East Africa in the 1950s, Nile perch remained in low abundance for several decades, and then expanded rapidly in the 1980s, leading to the extinction of between 200 and 400 endemic cichlid species, as well as several other native fish species (Balirwa et al. 2003). It has been estimated that, at any given time, over 10000 marine species are being transported between biogeographic regions in ships' ballast water (Carlton 1999). Ninety-one percent of approximately 400 marine species in Pearl Harbor, Hawai'i have been introduced from other areas (Coles et al. 1999).

The impact of invasive plants includes displacement of native species and alteration of soil chemistry, fire regimes, and hydrology (Cronk and Fuller 1995). In Bangladesh, the exotic shrubs, grasses, and vines that are typical of open habitats can invade regenerating forest and replace recovering primary forest species, such as dipterocarps (Islam et al. 2001). Similarly, previously logged sites in Madagascar have failed to recover their former native plant species diversity, owing to the dominance and persistence of invasive species (Brown and Gurevitch 2004).

\section{Climate change}

The physical evidence for recent climate change is overwhelming (IPCC 2007), and climate warming can affect species by (1) altering densities, (2) shifting ranges upward in elevation or poleward, (3) changing behavior, such as the phenology (seasonal timing of life-cycle events) of migration, breeding, and flowering, (4) changing morphology, such as body size, (5) altering physiological rates, such as maturation times, (6) shifting genetic frequencies and reducing genetic diversity, and (7) acting synergistically to exacerbate other human impacts (IPCC 2007). Although large fluctuations in climate have occurred throughout Earth's history, the implications for current biodiversity are particularly bleak, due to the speed with which change is occurring and the fact that landscapes are already heavily modified (Brook et al. in press). Evidence for some of these effects in tropical areas is currently sparse, but many observations and predictions suggest that climate change impacts will be, directly and synergistically, some of the most pressing conservation issues facing tropical species over the coming centuries.

Species living at higher altitudes in the tropics are particularly vulnerable to disruption of specific microclimates and the warming-induced influx of competitive, parasitic, or predatory invasive species from lower elevations (see section below). Increases in atmospheric $\mathrm{CO}_{2}$ are predicted to reduce cloud contact with high-elevation habitats and increase the rate of evapotranspiration in tropical montane forests, threatening the integrity of these unique ecosystems rich in endemic species (Still et

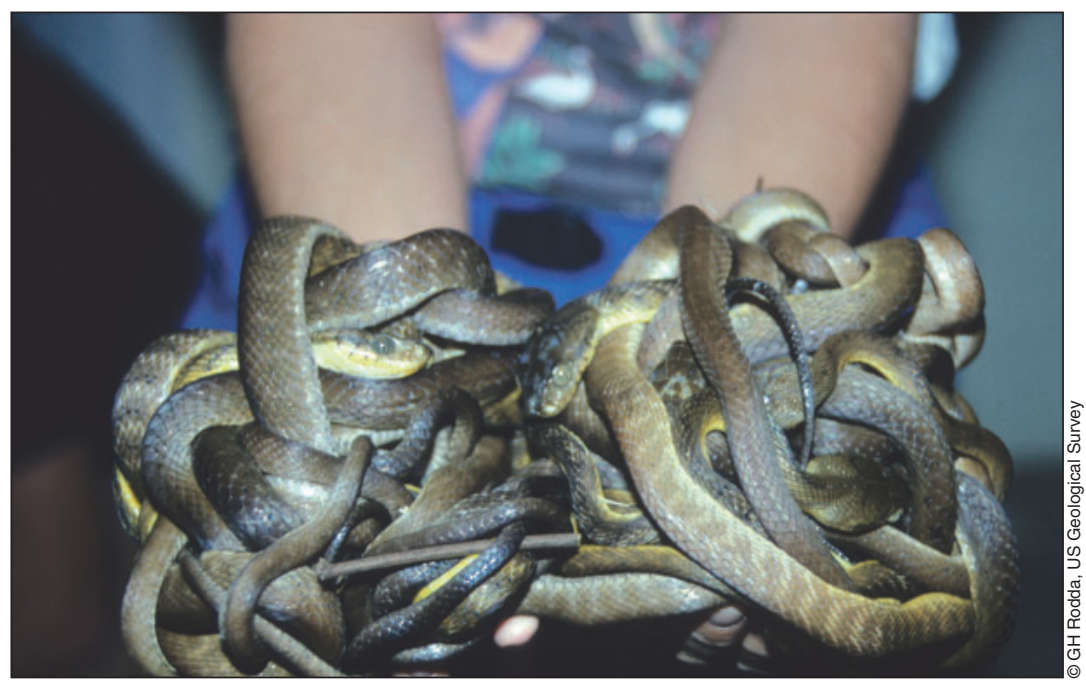

Figure 4. Invasive species: brown tree snakes (Boiga irregularis) hand-captured in a single night on the island of Guam. 

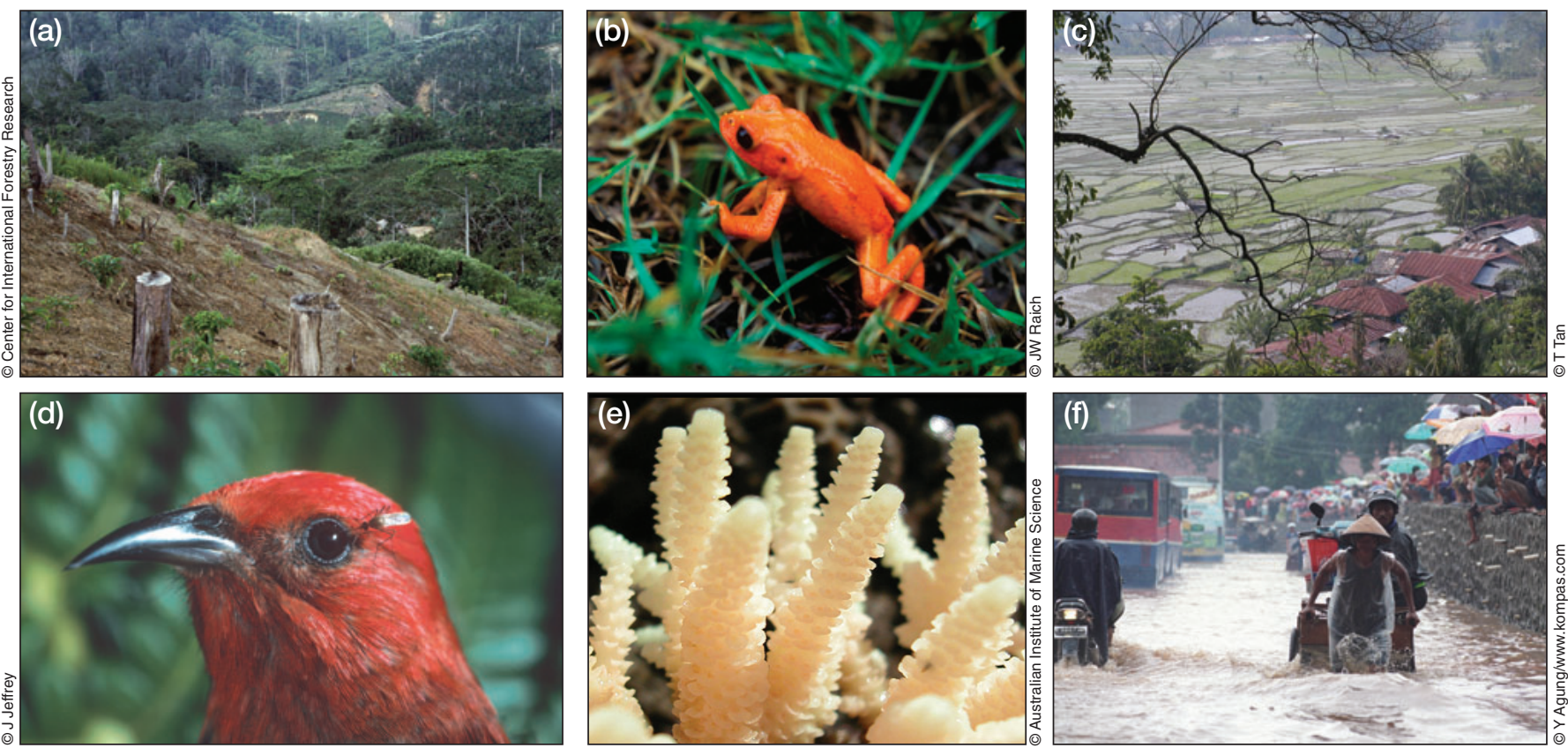

Figure 5. Examples of tropical turmoil. (a) Deforestation due to logging, (b) the now-extinct golden toad (Bufo periglenes) of Costa Rica, (c) intense rice agriculture in Southeast Asia, (d) Culex mosquito, vector of avian malaria (Plasmodium relictum), attacking a Hawaiian apapne (Himatione sanguine), (e) bleached Acropora millepora coral in the Great Barrier Reef, Australia, and $(f)$ devastating floods in Jakarta, Indonesia, linked to deforestation.

al. 1999). Peh (2007) found that shifting elevational distributions may have occurred in 94 resident bird species of Southeast Asia, a large proportion of which were probably forced toward higher elevations in response to climate warming. In general, these shifts result in restricted and fragmented range areas, lower population sizes, and higher extinction risk (Pounds et al. 1999).

Global climate change has altered, and will continue to alter, tropical disease-vector distribution and pathogen virulence (Harvell et al. 2002), and may generate new pathogens, especially in plants. The most severe disease outbreaks are predicted to occur if climate change causes species that were formerly separated to overlap. In the highland forests of Monterverde (Costa Rica), 40\% (ie 20 out of 50) of frog and toad species have disappeared following synchronous population crashes in 1987 (Pounds et al. 1999), with most collapses linked to warming of the local climate. Pounds et al. (1999) suggest that climate warming has resulted in a retreat of clouds and drying of mountain habitats, making amphibians more susceptible to fungi and parasites. Introduced avian malaria and pox (Poxvirus avium) in Hawai' $i$ have caused declines in many endemic birds (Atkinson et al. 1995). The upward shift in mosquito distribution predicted from continued global warming will probably reduce the refuge habitat available to endemic birds, with serious implications for the persistence of some of the least adaptable species (Harvell et al. 2002). It has been predicted that a $2^{\circ} \mathrm{C}$ rise in global temperatures will effectively wipe out all remaining diseasefree forested refugia in Hawai' $i$ within the next century (Benning et al. 2002).

Coral bleaching - a warming-induced tolerance thresh- old process by which the coral animal host expels its symbiotic algae (Figure 5e) - appears to have increased in frequency and magnitude over the past several decades (Reaser et al. 2000). The factors thought to be responsible for bleaching - primarily changing seawater temperatures, but also rising salinity, increased exposure to air due to tidal changes, increased sedimentation leading to reduced light penetration, and higher solar radiation are all predicted to be enhanced under various climatechange scenarios (Fitt et al. 2001).

\section{Loss of ecosystem function and services}

That the loss of tropical biodiversity will continue to increase in severity over the coming decades is cause enough for concern - but what are the implications for humanity? The disruption of ecological processes may lead to cascading co-extinctions. For instance, many tropical trees produce large, lipid-rich fruits adapted for animal dispersal, so the demise of frugivores may have serious consequences for forest regeneration, even if the initial drivers of habitat loss and degradation are controlled (Sodhi et al. 2007). Essential ecosystem functions provided by forest invertebrates are also highly susceptible to the loss of species (Koh et al. 2004).

In addition to unabated rates of forest loss, coastal development, overfishing, and catchment modification, habitat conversion is proving to be directly damaging to human well-being. Plants and soil store between 460 and 575 billion metric tons of carbon and, after fossil-fuel consumption, human modification of vegetation and soils are the next major source of anthropogenically 
derived carbon (Flint 1994). Tropical forest loss is currently responsible for $20 \%$ of current global emissions (IPCC 2007), and it is believed that deforestation in Southeast Asia alone releases approximately 465 million tons of carbon into the atmosphere annually (Phat et al. 2004), representing 29\% of the total global carbon release due to deforestation.

Forests assist in regulating water flow to downstream areas. Thus, deforestation can alter the natural water flow of an area, resulting in either flood or drought episodes. Indeed, there is a clear relationship between native forest cover and the incidence and severity of floods in the developing world (Bradshaw et al. 2007; Figure 5f). Forest canopies reduce the force with which rainwater strikes the soil, thereby reducing erosion, and tree roots bind soil so that it is less likely to be washed away during flooding. Loss of topsoil due to deforestation can reduce rice output by 1.5 million tons per year, an amount that would feed up to 15 million people per year globally (Magrath and Arens 1989). Deforestation-driven siltation may also reduce the lifespan of dams, clog natural waterways, and impact offshore fisheries. Forest ecosystems are responsible for the regulation of about half of the world's water drainage systems, upon which roughly five billion people rely for water supplies (MA 2005). Tropical forests are a source of food, remedies, natural products, and construction materials for many local communities (Laurance 1999). At least $25 \%$ of medicines patented by Western pharmaceutical companies are derived from plants identified and prepared through traditional indigenous techniques (Sodhi et al. 2007). The destruction of rainforests can also facilitate the spread of human diseases, such as malaria and other arthropod-borne pathogens.

Deforestation clearly has ramifications beyond the direct effects of biomass removal and degradation. Almost all flowering plants in tropical rainforests are pollinated by animals, and an estimated one-third of the human diet in tropical countries is derived from insectpollinated plants (Crane and Walker 1983). The predicted loss of bird species (13\% globally) by the year 2100 (BirdLife International 2000) will result in compromised seed dispersal and pollination. A decline of forestdwelling pollinators may impede plant reproduction not only in forests, but also in the neighboring agricultural areas (Sodhi et al. 2007). Many predators are important agents of biological control of pests in agricultural areas. It is estimated that natural predators, parasites, and pathogens of agricultural pests save humanity US\$54 billion annually (Naylor and Ehrlich 1997).

\section{- Conclusions and ways forward}

The above evidence makes it patently clear that tropical systems are in turmoil, leading us to conclude that a tropical biodiversity crisis cannot be avoided. Moreover, due to substantial inter-regional and local differences, both in terms of the relative impact of different threatening processes and the available economic and logistical capacity and willingness to conserve environmental assets, there can be no simple, overarching "solutions" to fix these problems (du Toit et al. 2004). Most tropical countries are developing nations, and so the available options are considerably constrained relative to developed nations (which have a poor environmental record anyway; MA 2005). Thus, because it seems inevitable that each region will be forced to deal with the most pressing issues as they arise, a multi-pronged conservation approach is needed to avert the worst outcomes.

Improvements in tropical logging practices and more stringent disincentives for illegal logging are the most immediate ways to conserve functional tropical forests. In addition, people are much more likely to protect their local natural systems if they believe that such conservation actions can benefit them directly, rather than intangibly. One way to achieve this is to demonstrate the key functional roles played by intact ecosystems in flood protection, sustainable food production, and delivery of clean water (Kareiva and Marvier 2007). Although controversial, direct monetary payments made in perpetuity, in which biodiversity is treated as a global market commodity or societal investment, have also been proposed (Nicholls 2005).

In our opinion, however, the greatest long-term improvements can be made in governance of tropical biodiversity resources. Political corruption is rife in many tropical countries (Sodhi et al. 2007), and this has been correlated with poor biodiversity conservation outcomes, as corruption reduces effective funding and overlooks illicit overexploitation of forests, wildlife, fisheries, and other natural resources (Smith et al. 2003). Soares-Filho et al. (2006) showed that the establishment of good governance (ie implementation of all environmental legislation) by 2050 could eliminate deforestation from protected areas in the Amazon, and reduce it by 35\% in unprotected forests. Good governance will only come from strong multilateral policy and concomitant socioeconomic and administrative aid. This is feasible if a large proportion of funds come from carbon-offset programs under an international emissions trading scheme, operating within the UN Framework Convention on Climate Change (http://unfccc.int). Richer nations can also assist developing countries directly through the training of resource managers and bureaucrats. The development of stronger collaborations among national, regional, and international groups is a positive step toward maximizing the persistence of good environmental governance. Perverse subsidies, which have adverse effects on the environment as well as society, must be removed (MA 2005).

The multiple anthropogenic pressures now impinging upon tropical biodiversity threaten ecosystem function and the essential services provided by ecosystems to humanity (Sodhi et al. 2007). There is currently little reason to be optimistic about the fate of tropical biodiversity. Indeed, we argue that the recent debate over predicted extinction rates masks the real issue - the precautionary 
principle demands that we err on the side of caution (Laurance 2007) to avoid inadvertently supporting political agendas based on unjustified optimism, which could result in further destruction of biodiversity values. We must not accept the belief that all is well in the tropics, or that the situation will improve with economic development, nor use this as an excuse for inaction on the vexing conservation challenges of this century.

\section{Acknowledgements}

This project was funded by the National University of Singapore (R-154-000-264-112) and Charles Darwin University. We thank D Bickford, B Campbell, R Chazdon, R Corlett, T Cunningham, R Dunn, T Flannery, L Koh, M Lim, K Peh, M Meekan, MR Posa, C Sekercioglu, H Tan, and K Wertz for comments, contributions, and assistance. Many thanks to Y Agung, the Australian Institute of Marine Science, the Center for International Forestry Research, J Jeffrey, JW Raich, GH Rodda, and C Sekercioglu for providing photos.

\section{References}

Adeel Z and Pomeroy R. 2002. Assessment and management of mangrove ecosystems in developing countries. Trees 16: 235-38.

Alvard MS, Robinson JG, Redford KH, et al. 1997. The sustainability of subsistence hunting in the Neotropics. Conserv Biol 11: 977-82.

Achard F, Eva HD, Stibig H-J, et al. 2002. Determination of deforestation rates of the world's humid tropical forests. Science $\mathbf{2 9 7}$ 999-1002.

Antheaume B, Bonnemaison J, Bruneau M, et al. 1995. Géographie universelle. Asie du Sud-Est, Océanie. Paris, France: Hachette.

Atkinson CT, Woods KL, Dusek RJ, et al. 1995. Wildlife disease and conservation in Hawaii: pathogenicity of avian malaria (Plasmodium relictum) in experimentally infected iiwi (Vestiaria coccinea). Parasitology 111: S59-S69.

Balirwa JS, Chapman CA, Chapman LG, et al. 2003. Biodiversity and fishery sustainability in the Lake Victoria basin: an unexpected marriage? BioScience 53: 703-15.

Barlow J, Gardner TA, Araujo IS, et al. 2007. Quantifying the biodiversity value of tropical primary, secondary and plantation forests. P Natl Acad Sci USA 104: 18555-60.

Bennett EL. 2002. Is there a link between wild meat and food security? Conserv Biol 16: 590-92.

Bennett EL, Nyaoi AJ, and Sompud J. 2000. Saving Borneo's bacon: the sustainability of hunting in Sarawak and Sabah. In: Robinson JG and Bennett EL (Eds). Hunting for sustainability in tropical forests. New York, NY: Columbia University Press.

Benning TL, LaPointe D, Atkinson CT, and Vitousek PM. 2002. Interactions of climate change with biological invasions and land use in the Hawaiian Islands: modeling the fate of endemic birds using a geographic information system. P Natl Acad Sci USA 99: 14246-49.

BirdLife International. 2000. Threatened birds of the world. Barcelona, Spain and Cambridge, UK: Lynx Edicions and BirdLife International.

Bradshaw CJA, Sodhi NS, Peh KSH, and Brook BW. 2007. Global evidence that deforestation amplifies flood risk and severity in the developing world. Glob Change Biol 13: 2379-95.

Brook BW, Sodhi NS, and Bradshaw CJA. Synergies among extinction drivers under global change. Trends Ecol Evol. In press.
Brooks TM, Mittermeier RA, da Fonseca GAB, et al. 2006. Global biodiversity conservation priorities. Science 313 : 58-61.

Brown KA and Gurevitch J. 2004. Long-term impacts of logging on forest diversity in Madagascar. P Natl Acad Sci USA 101: 6045-49.

Cardillo M, Mace GM, Gittleman JL, and Purvis A. 2006. Latent extinction risk and the future battlegrounds of mammal conservation. P Natl Acad Sci USA 103: 4157-61.

Carlton JT. 1999. The scale and ecological consequences of biological invasions in the world's oceans. In: Sandlund OT, Schei PJ, and Viken A (Eds). Invasive species and biodiversity management. Dordrecht, Netherlands: Kluwer Academic Publishers.

Clavero M and García-Berthou E. 2005. Invasive species are a leading cause of animal extinctions. Trends Ecol Evol 20: 110.

Coles SL, DeFelice RC, Eldridge LC, and Carlton JT. 1999. Historical and recent introductions of non-indigenous marine species into Pearl Harbor, Oahu, Hawaiian Islands. Mar Biol 135: $147-58$.

Crane E and Walker P. 1983. The impact of pest management on bees and pollination. London, UK: Tropical Development and Research Institute.

Cronk QCB and Fuller J. 1995. Plant invaders: the threat to natural ecosystems. London, UK: Chapman \& Hall and World Wide Fund for Nature.

DeFries RS, Houghton RA, Hansen MC, et al. 2002. Carbon emissions from tropical deforestation and regrowth based on satellite observations for the 1980s and 1990s. P Natl Acad Sci USA 99: $14256-61$.

Dirzo R and Raven PH. 2003. Global state of biodiversity and loss. Annu Rev Environ Resour 28: 137-67.

du Toit JT, Walker BH, and Campbell BM. 2004. Conserving tropical nature: current challenges for ecologists. Trends Ecol Evol 19: $12-17$.

Fa JE, Peres CA, and Meeuwig J. 2002. Bushmeat exploitation in tropical forests: an intercontinental comparison. Conserv Biol 16: $232-37$

Fa JE, Currie D, and Meeuwig J. 2003. Bushmeat and food security in the Congo Basin: linkages between wildlife and people's future. Environ Conserv 30: 71-78.

FAO (United Nations Food and Agriculture Organisation). 2007. State of the world's forests 2007. Rome, Italy: Food and Agriculture Organisation of the United Nations.

Fitt WK, Brown BE, Warner ME, and Dunne RP. 2001. Coral bleaching: interpretation of thermal tolerance limits and thermal thresholds in tropical corals. Coral Reefs 20: 51-65.

Flint EP. 1994. Changes in land use in South and Southeast Asia from 1880 to 1980: a data base prepared as part of a coordinated research program on carbon fluxes in the tropics. Chemosphere 29: $1015-62$.

Fritts TH and Rodda GH. 1998. The role of introduced species in the degradation of island ecosystems: a case history of Guam. Annu Rev Ecol Syst 29: 113-40.

Grainger A. 2008. Difficulties in tracking the long-term global trend in tropical forest area. P Natl Acad Sci USA 105: 818-23.

Hansen MC and DeFries R. 2004. Detecting long-term global forest change using continuous fields of tree-cover maps from 8$\mathrm{km}$ advanced very high resolution radiometer (AVHRR) data for the years 1982-99. Ecosystems 7: 695-716.

Harvell CD, Mitchell CE, Ward JR, et al. 2002. Climate warming and disease risks for terrestrial and marine biota. Science 296 : 2158-62.

Hughes AR, Byrnes JE, Kirnbro DL, and Stachowicz JJ. 2007. Reciprocal relationships and potential feedbacks between biodiversity and disturbance. Ecol Lett 10: 849-64.

Islam KR, Ahmed MR, Bhuiyan MK, and Badruddin A. 2001. Deforestation effects on vegetative regeneration and soil quality in tropical semi-evergreen degraded and protected forests of Bangladesh. Land Degrad Dev 12: 45-56. 
IPCC (Intergovernmental Panel on Climate Change). 2007. Climate change 2007: synthesis report. Contribution of Working Groups I, II and III to the fourth assessment report of the Intergovernmental Panel on Climate Change. Geneva, Switzerland: Intergovernmental Panel on Climate Change.

ISSG (Invasive Species Specialist Group). 2007. Global invasive species database. Auckland, New Zealand: World Conservation Union.

IUCN (International Union for Conservation of Nature). 2007. IUCN red list of threatened species. Gland, Switzerland: World Conservation Union.

Kareiva P and Marvier M. 2007. Conservation for the people. Sci Am Oct: $50-57$.

Klink CA and Machado RB. 2005. Conservation of the Brazilian cerrado. Conserv Biol 19: 707-13.

Koh LP, Dunn RR, Sodhi NS, et al. 2004. Species coextinctions and the biodiversity crisis. Science 305: 1632-34.

Laurance WF. 1999. Reflections on the tropical deforestation crisis. Biol Conserv 91: 109-17.

Laurance WF. 2007. Have we overstated the tropical biodiversity crisis? Trends Ecol Evol 22: 65-70.

Magrath W and Arens P. 1989. The costs of soil erosion on Java: a natural resource accounting approach. Washington, DC: World Bank.

Matthews E. 2001. Understanding the forest resources assessment 2000. Washington, DC: World Resources Institute.

MA (Millennium Ecosystem Assessment). 2005. www.millenniumassessment.org. Viewed 9 Apr 2008.

Milner-Gulland EJ and Bennett EL. 2003. Wild meat: the bigger picture. Trends Ecol Evol 18: 351-57.

Myers N, Mittermeier RA, Mittermeier CG, et al. 2000. Biodiversity hotspots for conservation priorities. Nature 403: 853-58.

Naylor R and Ehrlich P. 1997. The value of natural pest control services in agriculture. In: Daily $G(E d)$. Nature's services: societal dependence on natural ecosystems. Washington, DC: Island Press.

Nicholls H. 2005. The conservation business. PLoS Biol 2: e310.

Orme CDL, Davies RG, Burgess M, et al. 2005. Global hotspots of species richness are not congruent with endemism or threat. Nature 436: 1016-19.

Peh KS-H. 2007. Potential effects of climate change on altitudinal distributions in tropical birds. Condor 109: 437-41.

Peres CA. 2000. Effects of subsistence hunting on vertebrate community structure in Amazonian forests. Conserv Biol 14: 240-53.

Phat NK, Knorr W, and Kim S. 2004. Appropriate measures for conservation of terrestrial carbon stocks - analysis of trends of forest management in Southeast Asia. Forest Ecol Manag 191 283-99.

Pimm SL and Raven P. 2000. Extinction by numbers. Nature 403 : $843-45$.

Pounds JA, Fogden MPL, and Campbell JH. 1999. Biological response to climate change on a tropical mountain. Nature 398: $611-15$.

Reaser JK, Pomerance R, and Thomas PO. 2000. Coral bleaching and global climate change: scientific findings and policy recommendations. Conserv Biol 14: 1500-11.

Robinson JG and Bennett EL. 2004. Having your wildlife and eating it too: an analysis of hunting sustainability across tropical ecosystems. Anim Conserv 7: 397-408.

Sala OE, Chapin FS, Armesto JJ, et al. 2000. Global biodiversity scenarios for the year 2100. Science 287: 1770-74.

Sinclair ARE and Arcese P (Eds). 1995. Serengeti II: dynamics, management and conservation of an ecosystem. Chicago, IL: Chicago University Press.

Sinclair ARE, Mduma SAR, and Arcese P. 2002. Protected areas as biodiversity benchmarks for human impact: agriculture and the Serengeti avifauna. P Roy Soc Lond B Bio 269: 2401-05.

Smith RJ, Muir RDJ, Walpole MJ, et al. 2003. Governance and the loss of biodiversity. Nature 426: 67-70.

Soares-Filho BS, Nepstad DC, Curran LM, et al. 2006. Modelling conservation in the Amazon basin. Nature 440: 520-23.

Sodhi NS, Brook BW, and Bradshaw CJA. 2007. Tropical conservation biology. Oxford, UK: Blackwell Publishing.

Still CJ, Foster PN, and Schneider SH. 1999. Simulating the effects of climate change on tropical montane cloud forests. Nature 398: 608-10.

Stuart SN, Chanson JS, Cox NA, et al. 2004. Status and trends of amphibian declines and extinctions worldwide. Science 306: 1783-86.

van Riper C, van Riper SG, Goff ML, and Laird M. 1986. The epi zootiology and ecological significance of malaria in Hawaiian landbirds. Ecol Monogr 56: 327-44.

Vitousek PM, Dantonio CM, Loope LL, and Westbrooks R. 1996. Biological invasions as global environmental change. Am Sci 84: 468-78.

Whitmore TC. 1997. Tropical forest disturbance, disappearance, and species loss. In: Laurance WF and Bierregaard ROJ (Eds). Tropical forest remnants: ecology, management, and conservation of fragmented communities. Chicago, IL: University of Chicago Press.

Wilson KA, McBride MF, Bode M, and Possingham HP. 2006. Prioritizing global conservation efforts. Nature 440: 337-40.

Wright SJ. 2005. Tropical forests in a changing environment. Trends Ecol Evol 20: 553-60.

Wright SJ and Muller-Landau HC. 2006. The future of tropical forest species. Biotropica 38: 287-301.

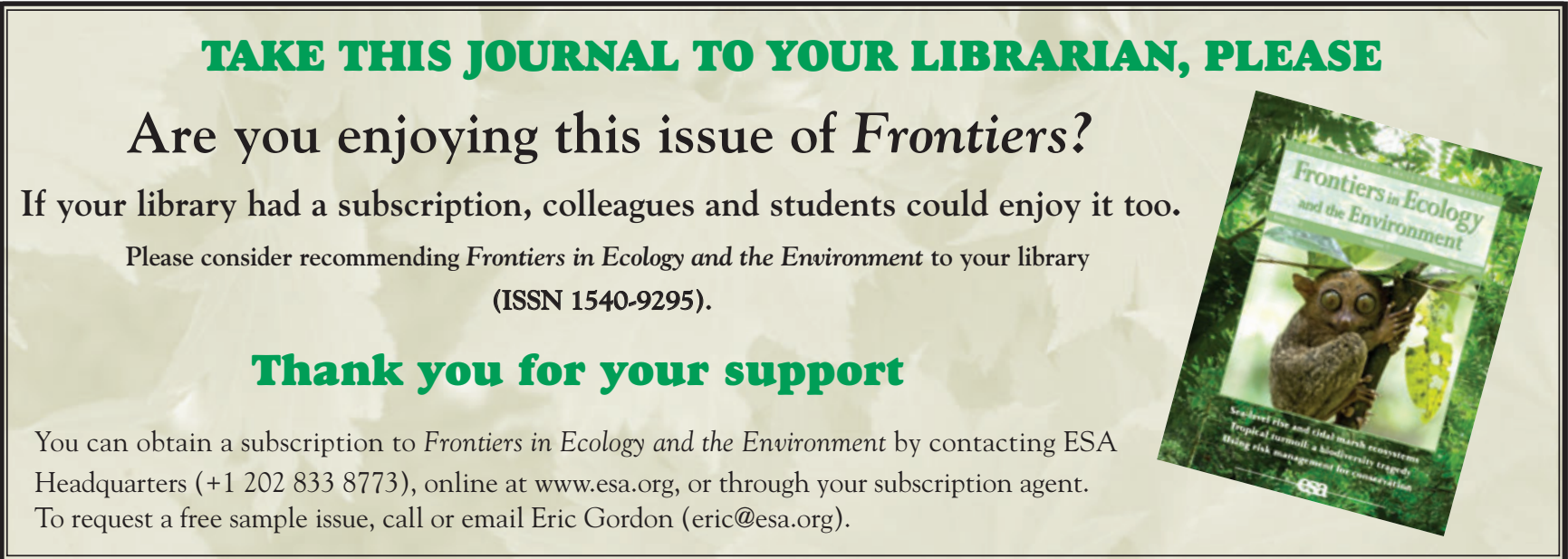

